\title{
A Critical Analysis of the African National Congress's Dominant Hegemonic Liberal Discourse
}

\author{
Mr. Teboho Bojabotsheha \\ Vaal University of Technology, Faculty of Human Sciences \\ Vanderbijlpark, 1900, South Africa \\ Email: teboho@vut.ac.za \\ Prof. Kholeka Constance Moloi \\ Vaal University of Technology, Faculty of Human Sciences \\ Vanderbijlpark, 1900, South Africa \\ Email: conniem@vut.ac.za
}

Doi:10.5901/mjss.2014.v5n1p313

\begin{abstract}
The objective of this paper is to engage in a critical analysis of the discourse of the ANC's 1999, 2004 and 2009 national election manifestos. The three texts draw from the resources of the genre of manifesto, perhaps the sub-genre of party election manifesto, and share certain common structural features. We argue that these texts also use ambiguous pronouns to ensure an affinity between the ANC and the audience, (i.e., masses) with respect to the achievements of an ANC-led government, assuring it about what work still needs to be done and thus positioning the ANC's vision as shared. Inherent in these texts are contrasting expressions, that we argue are used to denigrate the apartheid system (the segregationist regime prior to the 1994 South African democracy) and to laud the current democratic dispensation. What is also evident in all the three texts is the biased foregrounding of the ANC as the organisation which brought freedom to South Africans, leading the struggle for political, social, economic and educational transformation. It is silent about the contributions of the other political organisations to the emancipation struggle.
\end{abstract}

Keywords: African National Congress (ANC), critical discourse analysis, manifestos, foregrounding, symbolic and discursive resources

\section{Introduction}

Since the dawn of the South African democracy in 1994, the African National Congress (ANC) government has unceasingly continued to struggle towards increasing its electoral membership through its campaigns and election manifestos. According to Gumede (2005:ix), the ANC has had a difficult transition from liberation movement to governing party and it has attempted to modernise the ANC by transforming it into a heavily centrist party, while still retaining its mass support base. This paper particularly focuses on the ANC's 1999, 2004 and 2009 national election manifestos, considered in this paper in their textual format. They share certain common structural features of dominance, discrimination, power and control as manifested in language (Babbie \& Mouton, 2005:495).

Literature on the ANC political government is written from diverse angles, some studies addressing what the ANC has or has failed to achieve (e.g., Johnson, 2004), others the way in which political power operates and whether democracy has made a profound difference (Calland, 2006). However, our paper employs critical textual analysis of the discourse used by ANC in its 1999, 2004 and 2009 national election manifestos.

Babbie and Mouton (2004:495) point out that discourse analysis is a complex process that is better suited to those who are interested in theorising about life. In the context of this paper, the authors are interested in theorising about the ANC's 1999, 2004 and 2009 national election manifestos, seen as "shifting articulations of symbolic and discursive resources" (Chouliaraki \& Fairclough, 1999:21). We analyze them in terms of genre and its sequential structure, pronouns, intertextuality, contrasting expressions, grounding and elisions, statistics and figures, and the discourse of 'total freedom', which is actually an integral part of the dominant hegemonic, neo-liberal imperialist discourse of politics in South Africa fuelled by globalisation and the global economy imperatives. As pointed out by Gumede (2005:240), theorists such as Joel Netshitenzhe have dubbed as 'modernisation' the dramatic remake of the party from a loose liberation movement to a party with centrist social and economic policies, at ease with the market. 
The symbolic and discursive resources imply power relations (Pennycook 2003), revealing asymmetries of power between the ANC and other political formations in South Africa (Mesthrie, Swann, Deumert \& Leap, 2000). They also legitimise the ANC as a party that is fit to rule South Africa, and the authors make the point that the three manifestos are not only constituted by elements of other texts, such as the Freedom Charter, the Reconstruction and Development Programme and the Constitution of the Republic of South Africa, but also use statistics and figures to bestow the ANC with a systematic and scientific gravitas (Johnson, 2004:150). The use of statistics and figures creates an impression that the ANC's approach is serious and solemn, and not just based on intuition or gut feelings.

\section{Critical Discourse Analysis (CDA)}

According to Fairclough (1993:135), critical discourse analysis (CDA) aims to systematically explore often opaque relationships of causality and determination between discursive practices, events and texts, and wider social and cultural structures, relations and processes. It has to do with the investigation of how such practices, events and texts arise out of and are ideologically shaped by relations of power and struggle and how the opacity of this relationship between discourse and society is itself a factor securing power and hegemony (Fairclough 1999:135). Wodak (1995) provides a statement of the fundamental interest and aims of CDA as:

\section{... interested in analyzing opaque as well as transparent structural relationships of dominance, discrimination, power and control as manifested in language. In other words, CDA aims to investigate critically social inequality as it is expressed, signalled, constituted, and legitimized by language use (or in discourse) (Wodak 1995:204).}

The genealogy of CDA can be traced back to the Voloshinov/Bakhtin circle in the 1920s, and the recent work of Michel Pecheux, Jacob Mey and others (Luke 2002:97). Blackledge (2005) contends that there is no such thing as CDA, that is, no single theory or method that is uniform and consistent throughout (Blackledge 2005:2). It is an approach to the study of language influenced by diverse fields such as sociolinguistics, formal linguistics, social psychology and literary studies (Wodak 1995:205). Stated differently, the stances, positions and techniques of CDA vary (Luke 2002:98). Even the approaches of textual analysis found in CDA draw from diverse areas such as systematic linguistics, sociolinguistics, ethnography of communication, ethnomethodology, pragmatics and speech act analysis and narrative text grammar analysis (Luke 2002:98). The textual analytical approaches found in CDA include concepts from the Frankfurt School of critical theory, neo-Marxist, poststructuralist and feminist cultural studies, Bourdieuian sociology and, most recently, postcolonial and multiculturalist theory (Luke 2002:98). As Van Dijk (1993:279) contends, there are many ways to conduct critical discourse analysis.

For its enquiry, CDA does not focus exclusively on spoken and written texts. According to Wodak (1995:204), there is also a "theorization and description of both the social processes and structures which give rise to the production of a text, and of social structures and processes within which individuals or groups as social-historical subjects create meanings in their interaction with texts". Within an organisation, defined by Mumby and Clair (1997:181) as a social collective produced, reproduced and transformed through an ongoing, interdependent and goal-oriented communication practices of members, CDA focuses more closely on the question of power and control (Mumby \& Clair 1997:182). Van Dijk (1993:253) believes that it is the toughest challenge in the discipline and consequently requires "true multidisciplinarity, an amount of intricate relationship between text, talk, social cognition, power, society and culture". The following seven basic and broadly formulated questions inform critical discourse analytic research:

- How does the naturalisation of ideology come about?

- Which discursive strategies legitimate, control or naturalise the social order?

- How is power linguistically expressed?

- How are consensus, acceptance and legitimacy of domination manufactured?

- Who has access to which instrument of power and control?

- Who is discriminated against and in what way?

- Who understands a certain discourse, in what way, and with what results (Wodak 1995:205)?

Having briefly examined CDA, the authors now dsicuss the social, economic and political contexts that framed the three election manifestos of 1999, 2004 and 2009.

\section{Social, Economic and Political Contexts that Framed the Election Manifestos of 1999, 2004 and 2009}

In the Preface to the Reconstruction and Development Programme (RDP) document, former state president Nelson 
Mandela (1994) contends that "democracy will have little content, and indeed, will be short lived if we cannot address our socio-economic problems within an expanding and growing economy". These problems, rooted in the country's history of colonialism, racism, apartheid, sexism and repressive labour policies (RDP 1994:2), are considered by many writers from a variety of perspectives (Johnson, 2006).

The South African Constitution of 1996 and the 1997 Act and White Paper directed the state and institutions to realise profound and wide-ranging imperatives and goals in and through higher education. It was assumed that their progressive substantive realisation would contribute immeasurably to the transformation and development of higher education and society. The Constitution committed the state and institutions to uphold the values of human dignity, the achievement of equality, the advancement of non-sexism and non-racialism and to "respect, protect, promote and fulfil the rights" embodied in the Bill of Rights (Republic of South Africa, 1996).

The Higher Education Act (1997) declared the desirability of creating "a single coordinated higher education system", restructuring and transforming "programmes and institutions to respond better to the human resource, economic and development needs", redressing "past discrimination", ensuring "representivity and equal access" and contributing "to the advancement of all forms of knowledge and scholarship, in keeping with international standards of academic quality". The Act also proclaimed that it was "desirable for higher education institutions to enjoy freedom and autonomy in their relationship with the State within the context of public accountability and the national need for advanced skills and scientific knowledge".

The fundamental economic problem which South Africa needed to solve involved meeting the basic needs of the majority of its people (ANC, 1994), summarised by Harris (1997:91) as "raising the majority's standard of living by investing in housing, education and health". On this list, the RDP (1994:7) included jobs, water, electricity, telecommunication, transport, a clean and healthy environment, nutrition and social welfare. Tackling these, together with South Africa's large scale unemployment, would constitute significantly to overcoming the legacy of apartheid (Michie 1997:155). Poverty, viewed by Frye (2006) as "a basic state of existence for millions of South Africans", and unequal patterns of income and wealth distribution, however, are considered in this paper to be fundamental to any understanding of socio-economic problems which beset South Africa before the 1999 national democratic election. Indeed, as alluded to by Calland (2006:xiii), despite the dramatic change of 1994, the great majority of South Africans remain marginalised from real power and excluded from full participation in society due to chronic unemployment and poverty. This should not come as a surprise because centuries of colonial and apartheid policies had ensured that the majority were disadvantaged by oppressive conditions (Frye 2006). We argue that it is this context, defined by social, economic and political problems mentioned above, which frames the ANC 1999, 2004 and 2009 election manifestos.

\section{Critical Discourse Analysis of the ANC Election Manifestos}

For the purpose of this paper, the ANC 1999, 2004 and 2009 election manifestos can be seen, following Chouliaraki and Fairclough (1999:21), as "shifting articulations of symbolic/discursive resources (such as genre, discourse, voices) which themselves come to be articulated into relative permanence as moments of discourse, and transformed in that process". Like other manifestos, they present the "strategic direction and outlines of prospective legislation" (Scruton 1982:358), to be expected in the event the organisation received enough votes from the electorate to serve in government.

The 1999 manifesto, entitled Change Must Go on at a Faster Pace! was divided into seven sections, namely: (i) Message from the President; (ii)Why vote ANC? (iii) Five Years of ANC Government; (iv) Together, in Every Sector, Fighting for Change; (v) The Next Five Years - Our Vision; (vi) The Next Five Years - Our Programme; and (vii) Many Things to Do (ANC 1999). The 2004 manifesto, entitled A People's Contract to Create Work and Fight Poverty, unlike the 1999 manifesto, was divided into ten sections: (i) Message from the President; (ii) Celebrating Freedom; (iii) Celebrating South Africa; (iv) Actual Progress Gives Us; (v) Real Hope for the Future; (vi) Learning from Experience: We can do more, better; (iv) Why a People's Contract?; (vii) Vision 2014 - Forward to the Second Decade of Freedom; (viii) The Next Five Years: The Practical Steps; (ix) The Next Five Years: How will this be done?; and (x) Confidence in the Future (ANC, 2004). Lastly, the 2009 ANC manifesto, entitled Working Together, We Can Do More, had only six sections: (i) Message from the President; (ii) Proud of our Past, Confident of the Future; (iii) Our Manifest is clear and Achievable; (iv) Together we have achieved much; (v) Our Plan for the Next Five Years; and (vi) Conclusion (ANC 2009).

There are polarised views about the value of party election manifestos, with a number of negative views. For example, Lemon (2009: 9) asserts that in most democracies few people actually read them, but that what matters is popular perception of a party's identity and what it stands for. Expanding Lemon's view, Maluleke (2009) suggests that party election manifestos are over-rated, finding the ANC 2009 election manifesto particularly long and complex for the 
illiterate voter. Maluleke (2009:1) cynically argues that party election manifestos seldom persuade voters and should be seen as one of several factors, including gifts of beer and braai (barbecues), which influence people's voting choices.

To McKinley (2009), election manifestos are essentially propaganda tools containing very broad visions of the respective political parties, thinly sketched frameworks for societal development and a host of promises around more specific policy problems and challenges. However, one can challenge this assertion by pointing out that the ANC, like other governments globally, makes use of other mechanisms to achieve the goals for social development, for example, higher education. The White Paper on Reconstruction and Development (RDP) of 1994 identified various social purposes that higher education was intended to serve, one of which is to "address the development needs of society" and "the problems and challenges of the broader African context" (RDP 1994:1.3, 1.4). This resonates with Mumby and Clair's (1997:181) view, cited elsewhere in this paper, of organisation as a social collective produced, reproduced and transformed through a continuing, interdependent and goal-oriented communication practice of members.

Petlane (2009:1), a researcher in the Governance and African Peer Review Mechanism (APRM) in the South African Institute of International Affairs (SAlIA), believes that party election manifestos, hardly read by anyone, range from "mere sloganeering to monumental tomes packed with dry bureaucratic - academic - political - speak" (Petlane 2009:1). To this end, it is useful to borrow from Goffman's (1981, cited in Fairclough 2003:12) distinction between 'principal', 'author' and 'animator' of the text, with text in this case referring to the ANC election manifestos.

According to Goffman, 'principal' is the one whose position is put in the text; the 'author' is the one who puts words together and is responsible for the wording; and the 'animator' is the person who makes the sound of the marks on paper. A single person may occupy all these positions (Fairclough 2003:12). However, at the same time things may not be so, and without being embroiled into these complications the ANC is considered in this paper to have authored the three election manifestos.

Petlane's (2009:1) alternative to party election manifestos in their current form are 'demand-driven manifestos'. He would rather see individual and collective voters present parties and their candidates with lists of demands and enter into an agreement with prospective representatives to deliver on them. In the authors' schema such a stance suggested by Petlane would make the ANC election manifestos more inclusive, particularly of the masses (their voices) who continually vote, despite living in squalid conditions in under-developed environments.

Trapido (2009:2) is perhaps one of those who hold positive views about party election manifestos, arguing that they are clear demonstrations that the ANC has been listening to South Africans. He strongly endorses the continued affirmative action and BBBEE, welcomes the introduction of the National Health Insurance (NHI) and the attention paid to food security, especially during the time of global recession, and praises rural and agricultural development and land reform (Trapido, 2009:1-2). He considers the last two points as long overdue.

\subsection{Genre and sequential structure}

In our schema, the three ANC election manifestos suggest a specific sequential structure, share certain common structural features, in the sequence in which they appear, and distinguish this type of activity (manifesto in general and party election manifesto in particular) from job interviews, television documentaries, poems or scientific articles, for instance. These common structural features include message of the president; a statement of achievements, challenges and justification; vision; plans, programmes and implementation measures; and concluding remarks.

The three manifestos can be said to draw upon socially available resources of the genre of manifesto, and perhaps a sub-genre of party. Genre refers to "a relatively stable set of conventions that is associated with, and partly enacts, a socially ratified type of activity" (Fairclough 1999:126), such as the election manifestos. Simply, the term 'genre' refers to "a sort of language (and other semiosis) tied to a particular social activity, such as interview" or in the context of this paper the election manifesto tied to the ANC elections (Chouliaraki \& Fairclough 1999:63). We understand also that genre implies "a particular type text, but also a particular process of producing, distributing and consuming texts" (Fairclough 1992:126). Fairclough (1999) and Chouliaraki and Fairclough's (1999) definitions of genre serve our purpose very well, for what the analysis reveals about its sequential structure. Besides, there is no closed 'list' of genres or discourses and few that have stable names. At this stage, the authors now turn to a critical analysis of these features.

\subsubsection{Message of the President}

The three manifestos all begin with a 'Message from the President', former ANC and State President Thabo Mbeki for the 1999 and 2004 manifestos, and current ANC and State President Jacob Zuma for the 2009 manifesto. In each the 
central thesis was encapsulated in the title, urging the electorate to vote for the ruling party because it was the only political formation "that can speed up the journey to a better life" (ANC 1999:2) or "make change go on at a faster pace." It was bound, together with the people of South Africa, in "a people's contract to create work and fight poverty" (ANC 2004:2) and, because of its mass appeal, its widespread reach and capacity, the ANC "can get all of society working together to make change happen faster (ANC 2009:1).

\subsubsection{Achievements, challenges and justification}

The section on the message from the President is followed by a general discussion of the ruling party's record of achievements, challenges and some justification for the challenges experienced. In the 1999 election manifesto the ANC cited the implementation of non-racial education as but one of its achievements, claiming that "the majority of children enjoy better access to education, 10,000 new classrooms were built or upgraded and 1,5 million more children were brought into the education system" (ANC 1999:5). The same achievement is repeated in the 2004 election manifesto, as "more than 95\% [of children] were enrolled in primary schools, with feeding schemes in poor areas, financial assistance to those in need in universities, technikons, thousands of new classes built and new syllabus content introduced". In its 2009 election manifesto, the ANC contended with pride that it was just a few years away from achieving 100\% participation by all children in schooling, with the participation of girls being one of the highest in the world. It also maintained that more than 600,000 children attended crèches and pre-school (ANC 2009:5). Other achievements pertaining to education included:

- The rise in matriculation pass rate from $58 \%$ in 1994 to $65 \%$ in 2007 ;

- The reduction of overcrowding in classrooms whereby in 1996 there was one teacher for 43 learners. By 2006, there was one teacher for every 32 learners;

- The spread of mass literacy campaigns to more than 500,000 people who could not read and write;

- Support for 140,000 students in higher education, through the national financial scheme, to improve participation of the poor (ANC 2009:5).

The 1999 election manifesto was particularly detailed in its presentation of what had been achieved as well as on those sectors of the South African society which were presented with rights, opportunities and possibilities. These sectors include women, youth, workers, business people, rural people, traditional leaders, the aged, professionals and the disabled (ANC 1999:7-11). In its discussion about the achievements of the ANC-led government, the manifestos relied on what Zheng (2000:4) calls the "testimony" technique to list a series of achievements or its deeds.

In all the manifestos there was an acknowledgment that there were still challenges and much more that still needed to be done. For instance, in 1999 the ANC recognised as difficulties that need to be addressed: "inequality, lack of jobs, crime and corruption, poverty and the HIVIAIDS problem" (ANC 1999:3). Similar challenges were identified in 2004 as the manifesto stated: "despite the fact that 2 million net new jobs were created since 1995, the number of people seeking work has sharply increased; many workers have lost their jobs and many have been negatively affected by casualization and outsourcing" (ANC 2004:5). We also learned that poverty was still a reality for millions. Despite changes to the police, justice and other security structures and how they were conducting their operations, "too many attacks occur against citizens, the abuse of women and children is too high and violence against individuals remains a problem" (ANC 2004:5).

These challenges had not disappeared by 2009, and in the election manifesto the ANC accepted that unemployment was unacceptably high, especially amongst African women, rural people and they youth (ANC 2009:5). Even though poverty was not identified or seen as a challenge, inequality was clearly seen as a problem which had persisted and increased. Crime and corruption were also presented as major national challenges and action against them clearly needed to be stepped up (ANC 2009:5).

\subsubsection{Vision of the ANC}

Former State President Mbeki (2010) narrated a story about the United States of America (USA) President George H.W. Bush who was urged to address the bigger picture about America's future beyond the immediate and the short term. In a dismissive manner, the latter is reported to have responded: "oh, the vision thing". Mbeki (2010) contended that the US president's response translated into the unspoken words: 'I don't do the vision thing'. Unlike Bush, the third section of the three ANC election manifestoes outlined the vision of the organisation, which seems to have remained the same throughout the period of 1999-2009, eradicating apartheid and "building a truly united, non-racial, non-sexist and 
democratic South Africa" (ANC 1999:16; 2004:6; 2009:3). This vision was guided by the Freedom Charter, the Constitution and, initially, the ruling party's socio-economic and policy framework, the Reconstruction and Development Programme (RDP), amongst other documents. The Freedom Charter, which had been adopted at Kliptown in June 1955 (McKinley 1997), set out a list of demands grouped under the headings: (i) The people shall govern; (ii) All national groups shall have equal rights; (iii) The people shall share in country's wealth; (iv) The land shall be shared amongst those who work it; (v) All shall be equal before the law; (vi) All shall enjoy equal human rights; (vii) There shall be work and security; (viii) The doors of learning and culture shall be opened; (ix) There shall be houses, security and comfort; and (x) There shall be peace and friendship (McKinley 1997:20).

It is generally acknowledged that the Freedom Charter was a fundamental rallying point for the congress alliance engaged in the struggle against racial political oppression and economic imperialism (Johnson, 2005:150). However, some of its clauses (such as the economic one) have been amenable to widespread and controversial interpretations (McKinley 1997; Turok 2003). For instance, there continue to be debates over whether it is socialist in its orientation. The Constitution, on the other hand, continues to be a mechanism by which South Africans undertake, amongst other goals, to "build a united and democratic South Africa able to take its rightful place as a sovereign state in the family of nations" (1996:1). Non-racialism and non-sexism, amongst others, are fundamental founding values.

Lastly, the RDP was adopted by the ANC to realise its vision of eradicating apartheid and building a united, nonracial, non-sexist and democratic South Africa. Mbeki (2006) was of the view that the RDP constituted the core of the election manifesto of the ANC in South Africa's first democratic elections in 1994. Hirsch (2005:59), on the other hand, maintains that the RDP was published as the ANC manifesto before the elections, and, in a modified form, as a government White Paper later in 1994. The RDP was mainly an integrated programme, based on the people, aimed at providing peace and security for all, building the nation, and linking reconstruction and development and to deepen democracy (ANC 1994:7). In other words, its economic and political philosophy was based on six principles, namely: (i) An integrated and sustainable programme; (ii) A people-driven process; (iii) Peace and security for all; (iv) Nationbuilding; (v) Linking reconstruction and development; and (vi) Democratisation of South Africa (ANC 1994:4-7).

\subsubsection{Plans, programmes and implementation measures}

The section on vision is immediately followed by plans and programmes of the ruling party, as well as practical measures or steps it wished to implement to realise its vision. In 1999 the programme to accelerate change focused on five areas, namely: (i) Speeding up delivery of basic needs and developing human resources; (ii) Building the economy and creating jobs; (iii) Combating crime and corruption; (iv) Transforming the state; and (v) Building a better Africa and a better world (ANC 1999:14).

In 2004, the ANC's programme focused on the following areas: (i) A growing economy; (ii) Sustainable livelihoods; (iii) Access to services; (iv) Comprehensive social security; (v) Crime and corruption; (vi) Constitutional rights and governance; and (vii) Africa and the world (ANC 2004:7-9). In 2009, the ANC focused on five priority areas which it committed to tackle with all means at its disposal: (i) Creation of decent work and sustainable livelihoods; (ii) Education; (iii) Health; (iv) Rural development, food security and land reform; and (v) The fight against crime and corruption (ANC 2009:6).

\section{Other Linguistic Devices, Techniques and Strategies}

In To the Brink: The State of Democracy in South Africa (2008) Mangcu reports that he has asked one of the authors of the ANC's economic policy document, following the ANC July 2007 Policy Conference, why the ANC continued to present itself as a revolutionary organisation as the economic policy document was indeed littered with reference to the National Democratic Revolution (NDR) (Mangcu 2008:126). The response is reported to have to have been "quite unapologetic about the need to keep the base", which means that the ANC was said to be a brand and therefore had to keep its 'brand base', while also trying to attract new 'customers'. Thus, the way to keep 'brand loyalty' was through the language used, "To wit, a revolutionary party must speak to people in the language they understand even if it does exactly the opposite" (Mangcu, 2008:126).

At the heart of this language are linguistic devices, techniques and strategies used by the ANC to position itself as the only party in South Africa that was fit to govern. Below is a discussion of these devices, techniques and strategies. 


\subsection{Ambiguous pronouns}

The three ANC election manifestos are characterised by an ambiguity in their use of pronouns, such as we, our, et cetera. Firstly, there is an attempt to build up an affinity between the author of the manifestos and the audience pertaining to what has been achieved by the ANC-led government:

"The days of darkness are over: together we have ended apartheid rule"

"Our central challenge for the next five years is to use the experience we have gained, the policies we have put in place and the institutions of democracy we have created, to bring about even greater change than we have achieved in the first five years of democratic government"

"We must act together, in conditions of social discipline, further to give birth to a South Africa of freedom, prosperity and security for all, committed to act together to solve the national problems that confront all of us, including the advancement of national unity and reconciliation" (ANC 1999:1).

In the 2004 ANC national election manifesto we read:

"Our first ten years of freedom have been ten years of growing unity in action; ten years of peace and stability; ten years of increasingly making resources in the hands of the state available to uplift disadvantaged South Africans; ten years of expanding opportunities to build a better life for all"

"But we still have to reach the ideal of a society that truly cares"

"We have, in the ten years, brought water and electricity to millions of households"

"The journey that we have thus far travelled gives us confidence that we shall reach our goal of a society that cares" (ANC 2004:1).

The same inclusive pronouns are used to build up an affinity between the ANC and the audience with respect to the work which still needs to be done to better the lives of South Africans. The 2004 ANC national election manifesto promises:

"We will intensify our efforts to provide services and opportunities such as water and sanitation, health, electricity, housing and education to those South Africans who still do not have them"

"While expanding our economic base, we must ensure that the country's wealth, business opportunities, skills training and other opportunities are more equitably shared by all our people, irrespective of race, gender, disability and age differences"

"We must radically reduce the levels of unemployment and poverty, by combining the resources of the public and private sectors and built an economy that benefits all" (ANC 2004:2).

Lastly, there is also an attempt to build up an affinity between the ANC and the audience to position its vision as a shared one. The 2004 ANC election manifesto stated:

"Non-racialism, non-sexism and programmes to prevent other forms of discrimination are at the centre of our values and our practical actions"

"But we still have to reach the ideal of a society that truly cares"

"The journey that we have thus far travelled gives us confidence that we shall reach our goal of a society that cares" (ANC 2004:1).

In the 2009 election manifesto the ANC maintains:

"... We aspire to the creation of a nation united in diversity. It is a goal to which we all aspire and it is the path to achieving our shared goal for a better life for all" 
"We have to work together to weave the threads that will see us celebrating a nation which is non-racial, non-sexist and democratic - a nation that is dedicated to pushing the frontiers of poverty" (ANC 2009:1).

The use of inclusive pronouns such as 'we' and 'our' has the effect of blurring the distinction between the ANC and the audience. The audience becomes one with the ANC and, in this process of becoming, shares its achievements and failures. The use of these inclusive pronouns is actually consistent with the inclusive or "plain-folk" technique which, according to Zheng (2000:2), functions to assimilate the speaker into the group or groups and then to win the support of members of these groups. In this case the technique functions to include the ANC as a member or an integral part of all South Africans whose votes it is targeting. What the inclusive pronouns do as well is to bestow the ANC with the authority to speak not only as the ruling party in South Africa but also as a party of all the country - ruling on behalf of and together with all the potential electorate. The manifestos themselves are bestowed with the authority to speak, not only as manifestoes of the ANC but also as documents which belong to all South Africa, regardless of differences based on race, gender, class, et cetera.

Edward and Nicoll (2001) refer to a certain level of authoritarianism characteristic of this approach, since the manifestos present to the audience the ANC's views of what the vision of a South African society should be, what has been achieved and what still needs to be done. One of the effects of this authoritarianism is closure of spaces available for dissent and criticism of the ruling party, its vision and what is has done during the nineteen years of its rule in South Africa. However, the connection or identification between the ANC and the audience, established through inclusive pronouns such as 'we' and 'our', is at the same time severed through the exclusive pronoun 'you'. This occurs specifically in the identification of people who are responsible for the election of the ruling party in South Africa. In the 1999 ANC election manifesto we are told: "five years ago, you elected a government of the people to begin removing the terrible system of apartheid" (ANC 1999:1). There are skilful shifts in the manifestos' use of pronouns: from those of inclusion to those of exclusion; from 'we' (the ANC), 'we' (the ruling party in government) to 'we' (South Africans as a whole).

\subsection{Contrasting expressions}

The three manifestos draw a very sharp contrast between the apartheid system before 1994 and the ensuing democratic system. Specific contrasting expressions are used to portray the earlier period as diametrically opposed to the later one, from expressions such as 'darkness', 'oppression', 'exploitation', 'despair' and 'evil' to others such as 'light', 'the light of freedom', 'hope' and 'good'. The 1999 ANC election manifesto states:

"The days of darkness are over: together we have ended apartheid minority rule. The rays of dawn have begun to light up our horizon: the light of freedom is challenging the departing darkness of apartheid. The dark days of despair have given way to the season of hope" (ANC 1999:1).

Other terms used to describe the period of the apartheid system include 'neglect', 'violence and indignity', 'relations of hatred/enmity', 'not exemplary to the world', 'disrespect' and 'depravity'. Terms used to describe the period of the democratic system include 'better quality of life', 'peace and dignity', 'united nation', 'relations of friendship with the international community', 'exemplary to the world', 'respect' and 'fulfilment' (ANC 1999:1). The stark contrast helps lull the audience into identifying with the democratic system as well as the party, in this case the ANC, for having supposedly ushered in, singlehandedly, the above-mentioned revolutionary, progressive and transformative political system and all the achievements associated with it.

Any opposition to the ANC by implication is tantamount to nostalgia for and identification with the pre-1994 period and its characteristic evil system of apartheid, and opposition to the post-1994 period of democracy and accompanying achievements and successes brought about by the ANC.

\subsection{Grounding and elisions}

In all of the ANC election manifestos the ANC is foregrounded as the organisation which not only brought freedom to South Africa but also led the struggle for change and transformative vision. The 2004 election manifesto states:

"The change that happened 10 years ago was a result of struggle and sacrifice. Led by the African National Congress (ANC), it was change that created an opportunity for us to chart our future together" (ANC 2004: 3).

The ANC is also foregrounded as the organisation with an appropriate vision of a non-racial, non-sexist and 
democratic South Africa; an organisation which had accumulated the relevant experience to realise the said vision and had the capacity and resources to speed up "the journey to a better life" (ANC 1999:2). Through foregrounding, the ANC was positioned as an organisation which had improved the quality of life of all South Africans. This it did by:

"bringing water to 3 million people; housing nearly 3 million people; connecting 2 million households to electricity; improving health-care for the poor; transferring land to communities; implementing non-racial education and connecting telephone lines for 3 million people" (ANC 1999: 4-5).

The 2004 ANC election manifesto states:

"Throughout its 92 years of existence, the African National Congress has put the interests of all the people of South Africa at the top of its agenda" (ANC 2004: 1).

What is also evident in all of the ANC election manifestos under analysis is that nothing is said, whatsoever, about the engagement of other political parties challenging the political dominance of the ANC in South Africa. Evident here is their elision - or omission - which can be equated to their backgrounding. There is thus a foregrounding of the ANC and what it has done and a backgrounding, through elision, of other political parties in contention with the ANC for political hegemony in South Africa. The audience is made to believe that it is the ANC, and not any other political party, which laid the foundation and continues to strive for a better future for all. According to these election manifestos the ANC has been able to do this by:

"putting in place one of the best Constitution in the world; sweeping away racist and oppressive laws; introducing laws which provide for change; bringing equality of treatment of all and entrenching worker rights" (ANC 1999: 4).

These election manifestos conclude by reassuring the audience that "the ANC speaks with confidence because it has been at the head of this national effort to change our country for the better" (ANC 2004:10). Similarly, the 2009 ANC election manifesto reminded the audience that it was the ANC, not any other contending political party, which "has introduced laws to protect workers; created machinery to negotiate wages and working conditions; set minimum wages for domestic workers, farm workers, hospitality, taxi workers and security sectors and established maximum hours of work for all. [It is the ANC which has] introduced affirmative action laws and legislation to promote skills" (ANC 2009: 3). The 2009 ANC election manifesto brazenly stated:

"The ANC-led government [and not a DA-led government for example or any other party-led government which] has made much progress in the past 15 years, in the provision of housing, water and electricity to millions of homes" (ANC 2009: 1).

The ANC, according to the 2009 election manifesto, was "best placed to lead our country in the right direction, ensuring growth that is equitable and sustainable, as well as prosperity for all our citizens" (ANC 2009:2).

\section{Conclusion}

This paper has acknowledged that the 1999, 2004 and 2009 ANC election manifestos were framed by a context defined by social, economic and political problems, such as poverty, unemployment and inequality (PUI), rooted in South Africa's history of colonialism, racism, apartheid, sexism and oppressive labour policies. However, the application of a critical analysis of the discourse of the three texts has identified symbolic/discursive resources such as genre, ambiguous pronouns, contrasting expressions, grounding and elisions, statistics and figures and the discourse of total freedom and the use of these symbolic/discursive resources to achieve a number of objectives. The paper demonstrated that ambiguous pronouns have been used to ensure an affinity between the ANC and the audience with respect to the achievements of the ANC-led government, what work still needs to be done and to position the ANC's vision as a shared vision.

Contrasting expressions are used to disparage the apartheid system and to extol the democratic system. The three texts foreground the ANC as the organisation which brought democracy to South Africa and led the struggle for change. At the same time there is an elision of other political organisations and the role they played in the struggle for national democratic revolution (NDR) in South Africa. The authors also argued that the three texts, constituted by elements of other texts such as the FC, RDP and Constitution of RSA, use statistics and figures to bestow the ANC with 
a systematic and scientific gravitas. Lastly, in the three texts is a discourse of total freedom which is actually an integral part of the liberal discourse of politics in South Africa. All these symbolic or discursive resources function to position the ANC, as opposed to other political parties competing for political hegemony, as the only organisation which is fit to rule South Africa.

\section{References}

African National Congress (ANC) (1994). The RDP (Reconstruction and Development Programme): A policy Framework. Johannesburg: Umanyano.

African National Congress (ANC). (1999). 1999 Manifesto. [Online] Available: http://www.anc.org.za/elections/manifesto Imanifestotext.txt (May 31, 2010)

African National Congress (ANC) (2004). 2004 ANC Manifesto. [Online] Available: http://www.anc.org.za/elections/2004/manifesto /manifestoprt.html (May 31, 2010)

African National Congress (ANC) (2009). 2009 ANC Manifesto. [Online] Available: http://www.anc.org.za/elections/2009/manifesto Imanifesto.html (May 13, 2010)

Babbie, E. \& Mouton, J. (2004). The practice of social research. Oxford: University Press.

Badat, S. (2010). The challenges of transformation in higher education and training institutions in South Africa. Development Bank of Southern Africa (DBSA).

Blackledge, A. (2005). Discourse and Power in a Multilingual World. Amsterdam/Philadelphia: John Benjamins.

Calland, R. (2006). Anatomy of South Africa. Who holds the power? Cape Town: Zebra Press.

Chouliaraki, L. \& Fairclough, N. (1999). Discourse in Late Modernity: Rethinking critical discourse analysis. Edinburgh: Edinburgh University Press.

Edward, R. \& Nicoll, K. (2001). Researching the Rhetoric of Lifelong Learning. Journal of Education Policy, 16, 103-112.

Edward, R \& Nicoll, K. (2001). Researching the Rhetoric of Lifelong Learning. Journal of Education Policy, 16, 103-112.

Fairclough, N. (1992). Discourse and Social Change. Cambridge: Polity Press.

Fairclough, N. (1993). Critical Discourse Analysis and the Marketization of Public Discourse: The universities. Discourse Society, 4, 133168.

Fairclough, N. (2003). Analysing Discourse: Textual analysis for social research. London and New York: Routledge.

Frye, I. (2006). What is Poverty? A Qualitative Reflection of People's Experiences of Poverty. [Online] Available: http://www.naledi.org.za. (October 24, 2008)

Goffman, P. (1981). Forms of Talk. Oxford: Blackwell.

Harris, L. (1997). Economic Objectives and Macroeconomic Constraints. In J. Michie and V. Padayachee. (Eds.), The Political Economy of South Africa's Transition. Policy Perspectives in the Late 1990s (pp. 91-100). London: The Dryden Press..

Johnson, R.W. (2004). South Africa. The first man, the last nation. Johannesburg: Jonathan Ball.

Lemon, A. (2009). The Implications for Opposition Parties of South Africa's 2009 General Elections. Paper for presentation at the Democratization in Africa Conference, Leeds University, 4-5 December.

Luke, A. (2002). Beyond Sciences and Ideology Critique: Developments in critical discourse analysis. Annual Review of Applied Linguistics, 22, 96-110.

Maluleke, T.S. (2009). Much ado about election manifestos: Focus on the 2009 South African elections. Business Day, 15 January.

Mbeki, T. (2006). Nelson Mandela Memorial Lecture. University of the Witwatersrand, July 29.

Mangcu, X. (2008). To the Brink: The state of democracy in South Africa. Durban: KwaZulu-Natal University Press.

Mbeki, T. (2010). Address at the Black Management Forum Southern Africa Young Professionals Development Summit. Cape Town, August 19.

McKinley, D.T. (1997). The ANC and the Liberation Struggle: A Critical Political Biography. London, Chicago, Illinois: Pluto Press.

McKinley, D. T. (2009). South Africa: A critique of the ANC and Cope election manifestos. [Online] Available: http://links.org.au/node/953 (July 30, 2013)

Mesthrie, R., Swann, J., Deumert, A., \& Leap, L.L. (2000). Introduction to socio-linguistics. Edinburg: Edinburg University Press.

Michie, J. (1997). Developing the Institutional Framework: Employment and Labour Market Policies. In J. Michie and V. Padayachee. (Eds.), The Political Economy of South Africa's Transition. Policy Perspectives in the Late 1990's, (pp. 155-171). London: The Dryden Press.

Mumby, D.K. \& Clair, R.P. (1997). Organizational Discourse. In T.A. Van Dijk (Ed.), Discourse as Social Interaction, (Publications. pp. 181-205). London: Sage.

Pennycook, A. (2003). The Politics of Pronouns. English Language Teaching (ELT) Journal, 48, 173-178.

Petlane, T. 2009. Election Manifestos: Time for a different approach. [Online] Available: http://www.saiia.org.za/opinionanalysis/election-manifestos-time-for... (July 30, 2013)

Scruton, R. (1982). A Dictionary of Political Thought. London: Pan Books and Macmillan Press.

The Constitution of the Republic of South Africa, Act 108 of 1996.

Trapido, M. (2009). ANC Manifesto: South Africa First. [Online]. Available: http://www.thoughtleader.co.za/traps/2009/01/11/ancmanifesto-sout... (July 30, 2013) 
Turok, B. (2003). Nothing but the Truth: behind the ANC's struggle politics. Johannesburg and Cape Town: Jonathan Ball Publishers. Van Dijk, T.A. (1993). Principles of Discourse Analysis. Discourse and Society, 4, 249-283.

White Paper. (1994). Reconstruction and development. Parliament of South Africa. Government gazette, 353, No. 16085.

Wodak, R. (1995). Critical Linguistics and Critical Discourse Analysis. In J. Verschueren, J.O. Ostman \& J. Bommaert (Eds.), Handbook of Pragmatics Manual. Amsterdam/Philadelphia: John Benjamins Publishing Company. pp. 204-210.

Zheng, T. (2000). Characteristics of Australian Political Language Rhetoric: Tactics of gaining public support and shirking responsibility. [Online] Available: http://www.imi.se/intercultural/nr4/zheng.htm (June 21, 2007) 
